\title{
Investigation of Implementation Stages and Boundaries of Life Cycle Assessment Method
}

\author{
Ruveyda Komurlu \\ Department of Architecture, Faculty of Architecture and Design, \\ Kocaeli University, Kocaeli, Turkey \\ E-mail: ruveydakomurlu@gmail.com,ruveyda.komurlu@kocaeli.edu.tr \\ Recep Ahmed Buyukcinar \\ Architecture Program, Graduate School of Science and Engineering, \\ Kocaeli University, Kocaeli, Turkey \\ E-mail: mimarcht@gmail.com
}

\begin{abstract}
With the massive growth in the population of the world, the rapid consumption of natural resources and unorganized urbanization causes an impact of air pollution, water pollution, environmental destruction, and global warming to increase. With these factors threatening human health, the term sustainability gained popularity for restoring the deteriorating ecological balance. This awareness is called green buildings in the construction sector. The purpose of sustainable green buildings is the restoration of corrupted order and utilization of energy effectively. The Life Cycle Assessment method is one of the assessment systems developed for reducing the environmental impacts of products/services in evolving green buildings. Life Cycle Assessment determines the environmental impacts of the process that studies the extraction, use and disposal of the material by taking the life-long evaluation of any product. As a result of this study and the in-depth review of the literature portrayed the pros and cons, and the applications of the terms sustainability, green buildings and life cycle. The application stages of Life Cycle Assessment are defining the purpose and concept, stock analysis, analysis of effectiveness, evaluation of subfields with a determination of the boundaries as initial, intermediate and final. With the final analysis, the aim is to produce environmentally friendly products/services.
\end{abstract}

Keywords: Sustainability, Green Building, Life Cycle Assessment, LCA Application Steps, Construction Materials

DOI: $10.7176 / \mathrm{JSTR} / 6-13-01$

\section{Yaşam Döngüsü Değerlendirmesi Yönteminin Uygulama Aşamalarının ve Sınırlarının İncelenmesi}

Özet

Dünya genelinde artan nüfus ile birlikte doğal kaynakların hızla tüketimi, hatalı kentleşmelerden ötürü hava kirliliği, çevre kirliliği, su kirliliği ve küresel ısınma gibi unsurlar fazlasıyla artmıştır. İnsan sağlığını tehdit eden bu etkenlerin beraberinde, bozulan ekolojik dengeyi yeniden sağlamak adına birçok sektörde sürdürülebilirlik kavramı yaygınlaşmıştır. Yapı sektöründe de yeşil binalar olarak adlandırılan bu bilincin amacı, bozulan düzenin yeniden sağlanması ve enerjinin etkin şekilde kullanılmasıdır. Gelişen yeşil binalar ve değerlendirme sistemlerinin arasında ürün veya hizmetlerin çevresel etkilerinin tespitinin sağlanarak azaltılabilmesi için "Yaşam Döngüsü Değerlendirmesi (YDD)" yöntemi geliştirilmiştir. YDD, herhangi bir ürünün hayat boyu değerlendirmesini konu edinerek, malzemenin çıkartılması, kullanımı ve bertaraf edilmesine kadar devam eden sürecin çevresel etkilerini tespit eden bir analiz yöntemidir. Yapılan bu çalışma kapsamında literatür taraması yapılarak

1 | $\mathrm{P}$ a g e

www.iiste.org 
sürdürülebilirlik ve yeşil bina kavramları ile yaşam döngüsü değerlendirmesinin güçlü ve zayıf yönleri ve uygulandığı alanlar hakkında bilgi verilmiştir. YDD'nin uygulama aşamaları olan amaç ve kapsam tanımı, envanter analizi, etki analizi, yorumlama evreleri incelenerek, beşik, kapı, mezar kavramları üzerinden sınırları tanımlanmıştır. Elde edilen analizlerden ortaya çıkan sonuçların çevreye duyarlı yaklaşımlarla ürün veya hizmetlerin üretilmesinde fayda sağlanması beklenmektedir.

Anahtar Kelimeler: Sürdürülebilirlik, Yeşil Bina, Yaşam Döngüsü Değerlendirmesi, YDD Uygulama Aşamaları, Yapı Malzemeleri

\section{Giriș}

İkinci Dünya Savaşı sonrası kentleri dönüştürme çabaları, kontrolsüz büyümeyi körükleyen temel neden olmuştur. Bu kontrolsüz gelişme atık sorununu oluşturmuş ve zamanla büyüyerek bütün dünya ekosistemini tehdit edecek boyutlara ulaşmıştır. Günümüzde gelişen teknoloji neticesinde insanoğlunun çevreye ne derecede zarar verdiği kolaylıkla ortaya çıkmıştır. Oluşan su kirliliği, hava kirliliği, ışık ve görüntü kirliliği gibi etkenler zamanla birçok gönüllü kuruluşları harekete geçirerek dünya genelinde önlemler almaya yönlendirmiştir.

Yeryüzü ekosistemine zarar veren bu olumsuz değişimler ve gönüllü çalş̧malar zamanla sürdürülebilirlik kavramını ortaya çıkarmıştır. Bu kavram, sürdürülebilir kalkınma bakış açısıyla aralarında inşaat sektörünün de bulunduğu birçok önemli alanda kendine yer bulmuştur. Sürdürülebilirlik kavramının yanında artan çevre kirliliği sonucunda çeşitli sektörler de kullandıkları ürünlerin çevresel performansını denetlemeye, değerlendirmeye ve sertifikalandırmaya başlamıştır. İnşaat sektörü, her yıl dünya ormanlarının $\% 25$ 'ini, küresel ekonomi içindeki malzemenin $\% 40$ 'ını, 3 milyar ton hammaddeyi tüketmekte ve sera gazlarının ve asit yağmurunun küresel çıktılarının \%40\%50'sine sebep olmaktadır (CIWMB, 2000).

Mimarlık ve inşaat disiplininde çevreye duyarlı yaklaşımlar ile binaların üretilmesi için mimarlara düşen görev, çevreye saygıll, enerji tüketimini minimize eden, doğal kaynakların kullanımını azaltan yapılar oluşturmaktır. Ayrıca yenilenebilir ve yerel kaynaklar kullanılarak, sağlıklı iç mekânlar oluşturup, güneş enerjisini, doğal havalandırma ve doğal aydınlatmayı maksimize eden yeniden kullanılabilir ve geri dönüştürülebilir, sık sık bakım ve onarım gerektirmeyen malzemeler içeren tasarımlar yapmak da bir diğer başka bilinçtir (Çelebi ve Aydın, 2001).

\section{Sürdürülebilirlik ve Yeşil Bina}

Yaşam Döngüsü Değerlendirmesinden bahsetmeden önce sürdürülebilirlik, yeşil bina ve yeşil bina değerlendirme sistemleri tanımlarına yer verilmiştir.

\subsection{Sürdürülebilirlik Kavramı ve Tarihçesi}

Belirli bir amaç veya hedefin, denge içerisinde bugünden gelecek kuşaklara aktarılmasına sürdürülebilirlik denilmektedir. Sürdürülebilirlik, yaşam kalitesini düşürmeden, çevresel yönetim ve toplumsal sorumluluğun oluşmasını ve ekonomik çözümlerin ortaya konmasını hedeflemektedir (Özmehmet, 2005). Sürdürülebilir mimarlık bilincinde, toplumun her bireyine düşen yükümlülükten çok, ana tasarımcı mimar ve mühendislere oldukça büyük görevler düşmektedir. Çevreye olan sorumluluklarını göz ardı etmeyen tasarımcılar, enerjinin büyük bölümünü tüketen yapıların enerji harcamalarını minimize ederek, sürdürülebilirlik kavramına katkı sağlayacaklardır (Saka, 2011).

18. yüzyılda sanayinin yükselişiyle birlikte dünyanın gündeminde en üst sıralarda kendine yer bulan kalkınma kavramı, artan üretim ve tüketim ihtiyaçlarını beraberinde getirmiştir. Bu ihtiyaçlar zamanla sınır gözetmeyen bir şekilde doğal ve insan kaynaklarının tüketilmesine yönelik bir yaklaşıma neden olmuştur. Gittikçe artan eleştiriler, 1970 'lerin politik atmosferiyle de birlikte, dünyada kalkınma ve doğal çevre arasında bir denge kurma ihtiyacını tetiklemiştir. Tüm bu gelişmeler sürdürülebilirlik kavramının gündeme gelmesine zemin hazırlamıștır. 1970'lerden sonra kalkınma kavramı, sürdürülebilirlik kavramıyla birlikte anılmaya başlanmış olup, sürdürülebilirlik kavramı dünya üzerinde birçok kuruluş tarafından sahiplenilmiştir. Günümüzde Birleşmiş Milletler ise bu kuruluşların başında gelmektedir (Caradonna, 2014). İlk kez 1987'de Birleşmiş Milletler'in Brundtland Raporu ismini verdiği raporda bugünkü anlamıyla yer verilen sürdürülebilirlik kavramı, başlangıçta sürdürülebilir kalkınmayla özdeş bir şekilde kullanılmıştır. Kavram kısaca, bugünün gereksinimlerini, gelecek kuşakların gereksinimlerini karşılama yeteneğinden ödün vermeden karşılayan kalkınma, olarak tanımlanmıştır (Saka, 2011).

2 P a g e

www.iiste.org 


\subsection{Yeşil Binalar}

Sürdürülebilir kalkınmanın yapı sektörüne yansıması olarak bilinen yeşil binalar, daha az enerji ve su kullanma ve kullanılan malzemelerin çevresel hayat döngüsü üzerindeki etkilerini azaltma amacı güden tasarımlarla şekillenmektedir. Günümüzde yeşil binalar, yapı sektöründe daha değerli, doğaya saygıll, ekolojik ve enerji tüketimini azaltan yeni bina türleri ortaya çıkarmıştır.

Yeşil binalar yapıların insan ve çevre üzerindeki olumsuz etkilerini azaltmak amacıyla yapının arazi seçiminden başlayarak yaşam döngüsü süresince, bölgesel koşullara uygun, yenilenebilir enerji kaynaklarını, doğal ve atık üretmeyen malzemeleri kullanan, çevreye duyarlı şekilde tasarlanan yapılardır (Kömürlü ve Sayın, 2019, Kömürlü vd. 2013). Yeşil bina, bir binanın ve uygulandığı arazinin yerel iklim, arazi koşulları, kültür, çevre, kaynak kullanımı, kaynak tedariki ve yaşamın kalitesi ile çeşitliliğ̈inin artmasına yönelik biçimlendirilmesidir (Kömürlü vd., 2013, Adler vd, 2006).

\subsection{Yeşil Bina Değerlendirme Sistemi}

Çevre problemleri ve doğal kaynakların bilinçsizce kullanımı ve bu kaynakların tükenme noktasına gelebileceği düşüncesi, çevreye olan zararı en aza indirgeyen yeşil binaların yapılmasını gerektirmiştir. $\mathrm{Bu}$ sebeplerden dolayı yapılarda yeşil bina kriterlerinin sağlanabilmesi için bütün dünyada kabul gören çeşitli yönetmelikler ve yeşil bina değerlendirme sistemleri oluşturulmuştur (Özgünler, 2018).

Yeşil binaların yaygınlaşmasını amaçlayarak farklı ülkelerce geliştirilen sertifikasyon sistemleri, yapıların çevre üzerindeki etkisinin nesnel olarak ölçülmesinde referans sağlamaktadır. Yeşil binalar belirlenen sürdürülebilirlik ölçütlerine göre sertifika almaktadır (Kömürlü ve Arditi, 2017).

Yapıların çevresel etkilerini objektif ve somut olarak ortaya koyan yeşil bina değerlendirme sistemleri Yaşam Döngüsü Değerlendirmesi (YDD) yöntemi ve ölçütlere dayalı sertifika programları olmak üzere iki yöntemden oluşmaktadır. Ölçütlere dayalı sertifika programları daha objektif, daha kolay uygulanabilir ve sonuçlarının daha kolay anlaşıldığı yeşil bina değerlendirme sistemleridir (Kömürlü v.d., 2013). Yeşil bina değerlendirme sistemleri, yapıların çevresel etkilerini objektif ve somut bir şekilde ölçülebilir bir referans olmasını ve projenin belgelendirilmesini sağlamaktadır. Bu belgeleri alan kurumlar hem ekonomik hem de çevreye duyarlılık açısından avantaj sağlamaktadır. Bu bağlamda sertifikasyon sistemleri yaygınlaşarak, inşaat sektöründeki bilinçli tasarımcıların, yüklenicilerin ve kullanıcıların artmasını sağlayarak sürdürülebilir bir dönüşüm için geçişe öncülük etmektedir (Sayın, 2020).

\section{Yaşam Döngüsü Değerlendirmesi}

Yaşam Döngüsü Değerlendirmesi (YDD), bir ürün ya da hizmetin üretimi için kullanılan hammaddelerin elde edilme süreçlerinden, ilgili tüm üretim, sevkiyat, tüketici tarafından kullanım ve kullanım sonrası atık olarak bertaraf edilmeye kadar olan tüm süreçlerini incelemektir. Bu ürün veya hizmet üretiminin farklı aşamalarındaki çevresel etkilerini tespit etmek, raporlamak ve yönetmek için de kullanılmaktadır (Demirer, 2011).

Yaşam Döngüsü Değerlendirmesi tanımı TS-ISO 14040/Eylül 1995'de yayınlanan Türk Standardı'nda Hayat Boyu Değerlendirme olarak da bildirilmektedir. Tanım olarak kısaca, bir mal ve hizmet sisteminde belirli bir malzeme ve enerjiden elde edilen mal ve hizmetlerle, bu sistemin yaşam döneminde ortaya çıkan ve doğrudan doğruya sisteme atfedilebilen çevre etkilerine ait bilgilerin toplanması ve gözden geçirilmesiyle ilgili usuller dizisidir. ISO 14000 ve 14040 grubu standartlar çevre yönetimi ve yaşam döngüsü değerlendirmesi yöntemi ile ilgilidir ve bu konudaki en önemli çalışmalardandır (Kaya, 2010). YDD, "yaşam döngü analizi”, "yaşam döngü yaklaşımı”, "beşikten ölüme analiz" veya "ekolojik dengeleme" olarak da adlandırılmaktadır. Çevresel yönetimde ve uzun vadede sürdürülebilir gelişmenin sağlanmasına yardımcı olmada tasarlanan araç ve teknikleri içermektedir (Jensen vd., 1997).

\subsection{Yaşam Döngüsü Değerlendirmesi Tarihçesi}

Yaşam Döngüsü Değerlendirmesinin başlangıcı malzeme ve enerji kaynaklarında sıkıntı çekilen 1960’lara dayanmaktadır. Bu yıllarda daha çok değerlendirme ve kıyaslamaya yönelik çalışmalar yaygın olup YDD kullanım aşamasıyla çok fazla ilgilenilmemiştir. 1980'lerde Bekker'in yenilenebilir kaynaklar üzerine yaptığı çalışma ile YDD inşaat sektörünün de dikkatini çekmiştir. Bu dönemdeki erken çalışmalar, yöntemleri birbirinden farklı teknikler, terminoloji ve sonuçlar barındırmaktadır. 1990'lara gelindiğinde çalıştayların organize edilmesi, bazı makalelerin ve yardımcı kitapların yayınlanmasıyla birlikte bazı standartlar geliştirilmiştir. 2000 yıllarından sonra Çevresel Toksikoloji ve Kimya Topluluğu (Society of Environmental Toxicology and Chemistry, SETAC)

3 | P a g e

www.iiste.org 
Yaşam Döngü Değerlendirmesi konusunda uzmanları bir araya getirerek, terminoloji ve metodolojiyi "Code of Practice" (Uygulama Kuralları) adı altında yayınlamıştır (Buyle vd., 2013).

1994 yılından sonra International Organization for Standardization (ISO) konuya dâhil olarak 1997 yılında ilk defa basılan 14040 standart serisini oluşturmuştur (ISO 14040, 2006). Bu standart serisi, yöntem açısından bir çerçeve oluşturmuş ve farklı YDD çalışmalarının karşılaştırılabilmesi açısından kolaylık sağlamıştır (Yıldız, 2017).

\subsection{Yaşam Döngüsü Değerlendirmesi (YDD) Uygulama Alanları}

YDD uygulanmasının amacı, süreç içinde çevreye verilen hasarı önleyerek yanlış harcamaların önüne geçmektir. Bishop (2000), “Çevre Kirliliğinin Önlenmesi” adlı kitabında Yaşam Döngüsü Değerlendirmesi yapılmasının amaçlarını Şekil 1'deki gibi özetlemiştir. YDD yapılmasının ilk amacı ürün veya süreç geliştirmedir. Sonrasında ise maliyet azaltma, karar verme ve çevresel önlemler alma gelmektedir (Bishop, 2000). YDD çalışması firmalar tarafından, özellikle süreç içinde çevreye en çok zarar veren aşamaların tespit edilmesi ve bu noktalara gerekli müdahalelerin yapılması için tercih edilmektedir (Y1ldı, 2017).

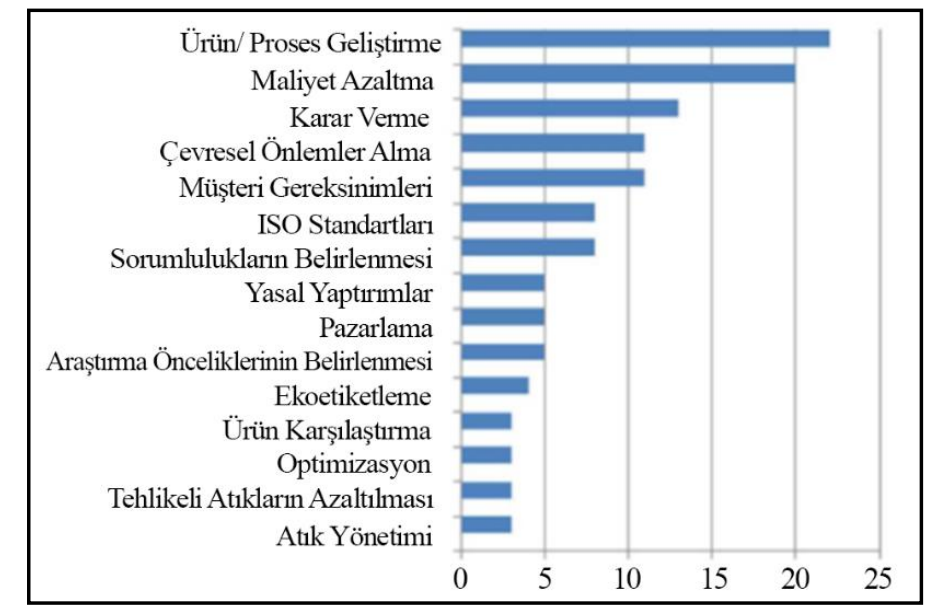

Şekil 1. YDD’nin Uygulama Alanları (Bishop, 2000, Çokaygil, 2005)

Uluslararası Standart ISO 14040’a göre YDD yöntemi kullanımı aşağıdaki alanlarda görülmektedir:

- Bir ürün veya hizmetin farklı yaşam döngüsü evrelerinde çevreyle ilişkisinin tanımlanarak bu ürün veya hizmetin geliştirilmesi ve iyileştirilmesinde,

- Kamuda ve özel sektörde, stratejik planlama, öncelik belirleme, ürün ve hizmetlerin tasarımı ve mevcut tasarımların yenilenmesi konularında karar verilmesinde,

- Ölçüm tekniklerini de içerecek şekilde çevresel performans göstergeleriyle ilgili kamu politikası oluşturulmasında,

- Çevresel bildirgeler ve çevre etiketi gibi pazarlama araçlarının geliştirilmesinde kullanılmaktadır (ISO 14040, 2006).

\subsection{Yapı Malzemelerinin Yaşam Döngüsü}

Kim ve Rigdon (1998), yapı malzemelerinin yaşam döngüsünü üç evrede ele almaktadır. Bunlar yapım öncesi, yapım ve yapım sonrası evre olup Şekil 2'de bu evreler ve kapsam alanları yer almaktadır. Yapım sonrası evre ile malzemeler, geri dönüşümle yapım öncesine kazandırılanlar, yapım evresi ile yeniden kullanılanlar ve atığa dönüştürülenler olarak üç farklı şekilde kullanılmaktadır (Kim ve Rigdon, 1998).

Yapı malzemelerinin malzeme veya bileşen bazında karşılaştırılması, iyileştirilmesi ve geliştirilmesi için malzemelerin yukarıda belirtilen yaşam döngüsü sürecinde çevresel etkilerinin değerlendirilmesi gerekmektedir. Ancak malzemelerin çevresel etkileri ülkeden ülkeye veya tesisten tesise farklılık gösterebilmektedir. Bunun nedeni de malzemeye üretim sırasında uygulanan değişik teknolojilerin ve yöntemlerin mevcut olması ile iklimsel farklılıklardır (Esin, 2007). 


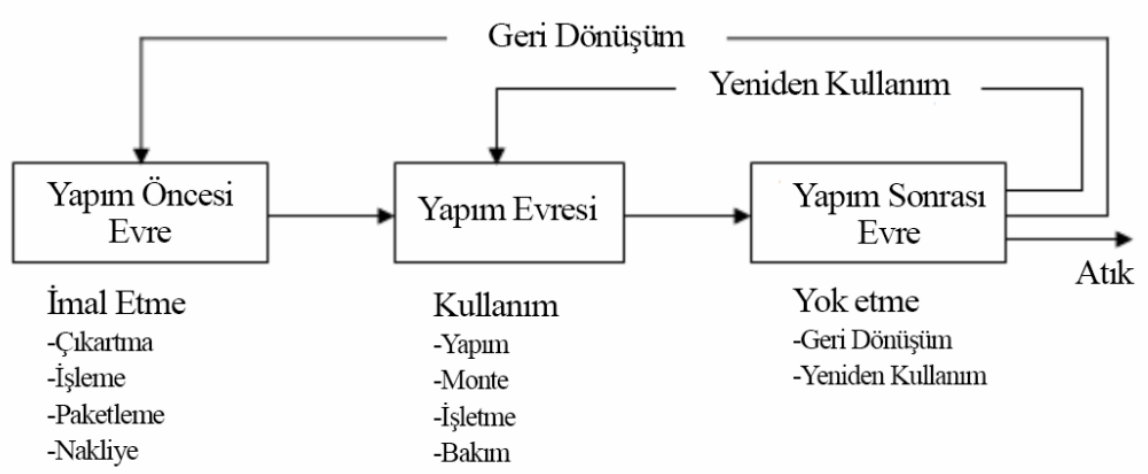

Şekil 2. Malzemenin Yaşam Döngüsü (Kim ve Rigdon, 1998)

\subsection{Yaşam Döngüsü Değerlendirmesinin Güçlü ve Zayıf Yönleri}

Yaşam Döngüsü Değerlendirmesi çalışmalarına başlamadan önce iki farklı başlıkta güçlü ve güçsüz yönler aşağıdaki şekilde belirtilmiştir.

\subsubsection{Güçlü Yönleri}

YDD güçlü yönleri için birçok örnek verilebilmektedir. Kamuda ve özel sektörde, stratejik planlama, öncelik belirleme, ürün ve hizmetlerin tasarımı ve mevcut tasarımların yenilenmesi konularında karar verilmesinde YDD yön göstermektedir. Ayrıca, ölçüm tekniklerini de içerecek şekilde çevresel performans göstergeleriyle ilgili kamu politikası oluşturulmasında, çevresel bildirgeler ve çevre etiketi gibi pazarlama araçlarının geliştirilmesinde önemli rol oynamaktadır. YDD, sanayi, hükümet ve tüketici temsilcilerinin alternatif proses, ürün ve malzemeler hakkında bilgi edinebilmesinde yarar sağlamaktadır. Ayrıca bir proses için referans bilgilerinin saptanmasında, prosesler incelendiği için eksik olan bilgilerin tespit edilmesinde ve eksikliklerin giderilmesinde de kullanılmaktadır (Demirer, 2011, Williams, 2009, Simonen, 2014).

\subsubsection{Zaylf Yönleri}

Ürünün ya da hizmetin, veri toplama, yaşam döngü envanteri verilerinin girilmesi, modellenmesi, değerlendirilmesi ve sonuçlarının raporlanması ciddi zaman ve emek harcanmasına sebep olmaktadır. Bunlar da YDD’nin zayıf yönleri arasında gösterilmektedir. YDD ürün ve hizmetlerin çevresel yönleri ile ilgilenirken, ekonomik veya sosyal nitelikleri ile ilgili herhangi bir çıktı üretememektedir. YDD yönteminde pek çok veri kaynağı, varsayım ve senaryo kullanılması çoğu zaman kaçınılmazdır. Başvurulan bu yöntemler nedeniyle aynı ürünün YDD'sinin çok farklı sonuçlarla sonlandırılabilmesi de ayrı bir dezavantaj olarak bilinmektedir (Demirer, 2011, Williams, 2009, Simonen, 2014).

\subsection{Yaşam Döngüsü Değerlendirmesinin Aşamaları}

Yaşam Döngüsü Değerlendirmesi 4 aşamadan oluşmakta ve belirli sistem sınırları içerisinde değerlendirilmektedir. Bunlar, amaç ve kapsam tanımı, envanter analizi, etki analizi ve yorumlama şeklindedir.

1. Amaç ve Kapsam; çalışmanın amacı, kapsamı, sınırları ve detaylandırma düzeyini, tanımlamaktadır.

2. Envanter Analizi; çalışılan sistemin kapsamı dâhilinde gerçekleşecek enerji, su, hammadde kullanımı ve bunlara bağlı olan çevresel emisyonların belirlendiği aşamadır.

3. Etki Analizi; bir önceki aşamada tespit edilen enerji, su, hammadde kullanımı ile çevresel emisyonların insan sağlığı ve çevresel değerler üzerindeki olası etkilerini değerlendirmektedir.

4. Yorumlama ve Sonuç; envanter ve etki analizi aşamalarının sonuçları değerlendirilir. İki ya da daha fazla YDD arasında karşılaştırma suretiyle çevreye verdiği yük açısından daha az olan ürün, süreç ya da hizmet seçilebilir. Bu seçim esnasında elde edilen verinin kalitesinin net olarak açıklanması gerekmektedir (Demirer, 2011). 
4 farklı aşamadan oluşan bu çalışmanın etkileşim bazından örgüsü Şekil 3'teki gibi belirtilmektedir. YDD yönteminde her bir evrede elde edilen sonuçlar, bir sonraki aşama için veri oluşturmaktadır (Demirer, 2011).

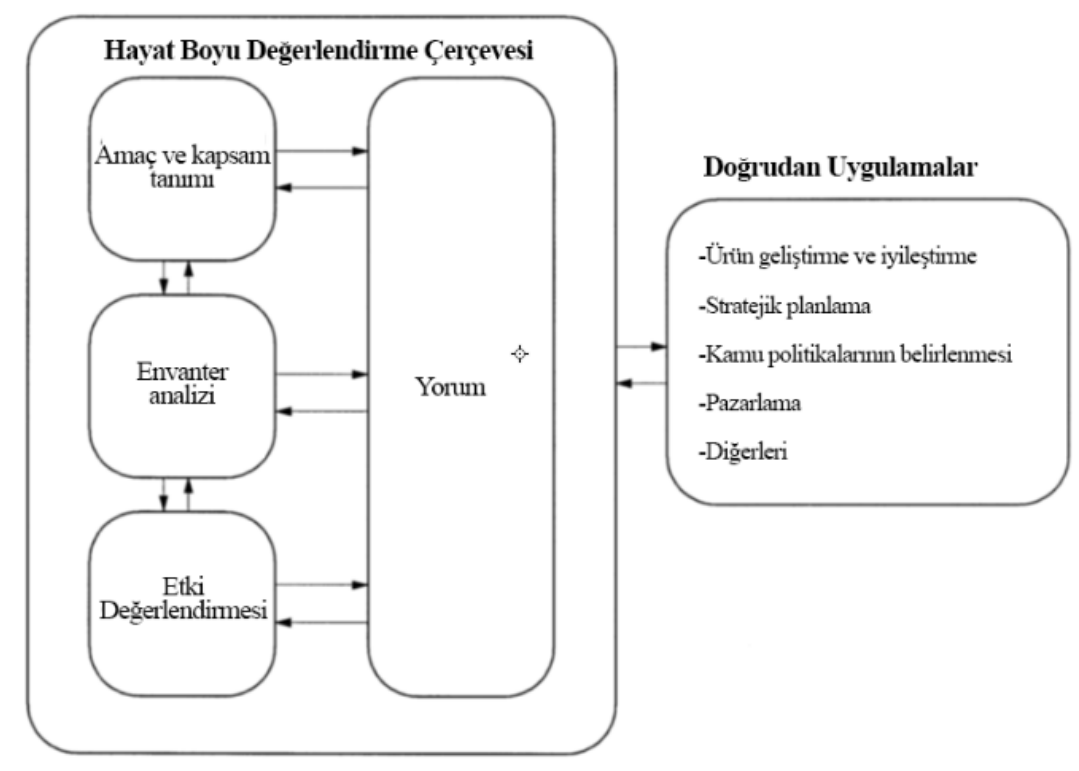

Şekil 3. YDD’nin ISO 14040’a Göre Tanımlanan Evreleri (Yıldız, 2017)

\subsubsection{Yaşam Döngüsü Değerlendirme Amaç ve Kapsam Tanımı}

Amaç ve kapsam tanımı, yaşam döngüsü değerlendirmesinin ilk aşamasıdır. YDD’nin amaç tanımı aşamasında; YDD'nin, tasarlanan uygulama, çalışmanın gerçekleştirilme sebepleri ve hedef kitle, şüpheye yer vermeyecek şekilde ifade edilmelidir. Kapsam tanımında, sistem ve sınırları (girdiler, çıktılar, üretim, dağıtım, nakliye, atık bertaraf senaryoları gibi işlem birimleri), veri gereksinimleri ve çalışmada yer alan tahminler belirtilmelidir. Kapsam, çalışmanın hedefini desteklemektedir. Amaç ve kapsam belirlemek, ne kadar zaman ve kaynağa ihtiyaç duyulacağını ortaya çıkaracağı gibi tüm analiz aşamalarına da yol gösterecektir. Hedef tanımı ve kapsam belirleme aşamasında alınan her karar, çalışmanın nasıl yönetileceğini ve nihai sonuçların uygunluğunu fazlasıyla etkileyecektir.

Etki değerlendirmesi metodolojisi ve etki tipleri, yorumlar ve veri gerekleri YDD'nin çalışmasının kapsamını oluşturmaktadır. Tanımlanırken ise; çalışılacak ürün sistemi, fonksiyonel birim, sistem sınırı, tahsisat prosedürleri, yaşam döngüsü, değer seçimleri, isteğe bağlı unsurlar, sınırlamalar, veri kalitesi gerekleri, çalışma için gerekli raporun tipi göz önünde bulundurulmalı ve açık bir şekilde tarif edilmelidir (TS EN ISO 14044, 2007). YDD’nin ilk aşaması olan kapsam tanımında çevresel etkileri değerlendirilecek olan yapı ürünü sistemi, bu sistemle ilgili kabul edilen varsayımlar, işlevsel birim, sistem sınırları, dağıtım yöntemleri ve veri kalite gerekleri tanımlanmalıdır. Eleştirel gözden geçirme ve rapor hazırlanmasıyla ilgili kararlar verilmelidir (ISO 14040, 2006).

\subsubsection{Yaşam Döngüsü Envanter Analizi (YDEA)}

Yaşam döngüsü değerlendirme yönteminin ikinci basamağı olan yaşam döngüsü envanter analizi, ürüne ve ürünü oluşturan süreçlere ait girdi ve çıktı miktarını belirlemek için oluşturulan veri toplama ve hesaplama evresidir. Şekil 4'te Yaşam Döngüsü Envanter Analizi (YDEA) aşamasında izlenilmesi gereken adımlar gösterilmektedir. 


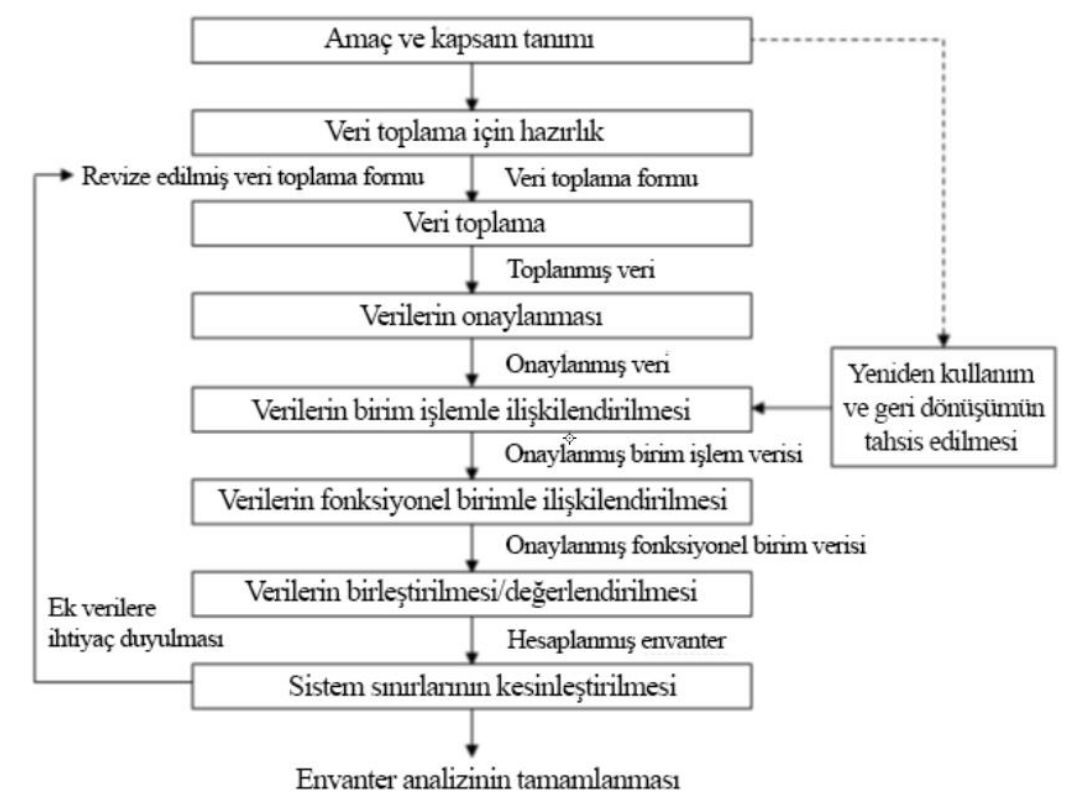

Şekil 4. Envanter Analizini Oluşturan Basamaklar (ISO 14044, 2006)

Envanter analizi, bir ürün sisteminin ilgili girdilerini ve çıktılarını hesaplamak için veri toplanmasını ve hesaplama prosedürlerini içermektedir. Sistem sınırı içerisindeki her birim süreç için veriler, enerji girdileri, hammadde girdileri, yardımcı girdiler, diğer fiziksel girdiler, ürünler, yan ürünler ve atık, havaya verilen emisyonlar, suya ve toprağa deşarjlar ve diğer çevresel boyutlardır (TS EN ISO 14044, 2007).

Bu süreçte, modellenecek ürün sistemlerinin aynı şekilde ve tutarlı olarak anlaşılmasının sağlanması için, modellenecek birim süreçlere ait genel süreç akış diyagramlarının çizilmesi, kullanılan birimleri belirten listenin geliştirilmesi, bütün veriler için veri toplama ve hesaplama tekniklerinin tarifi gerekmektedir. Veri toplama aşamasında, yeni gereksinimlerin ortaya çıkması ya da karşılaşılan sorunlar, bu evrenin tekrar gözden geçirilmesini sağlamaktadır. Hatta çalışmanın amaç ve kapsamına yönelik değişiklik yapılması ihtiyacını doğurabilmektedir (ISO 14040, 2006). Birbirini takip eden süreçlerden oluşan YDD’nin, birinci ve ikinci aşamaları, etki değerlendirmesinin sonuçlarının ne kadar hassas ve doğru tanımlandığını gösterir. Envanter analiz verilerinin toplanmasında gösterilen hassasiyet, sadece verilerin doğruluğunu sağlamakla kalmaz aynı zamanda harcanan süre ve kaynakların minimumda tutulabilmesini sağlamaktadır (Demirer, 2011).

\subsubsection{Yaşam Döngüsü Etki Değerlendirmesi (YDED)}

Yaşam döngüsü etki değerlendirme aşaması YDD'nin üçüncü evresidir. YDD’nin, bir ürün sistemi için ürünün faydalı ömrü boyunca muhtemel çevresel etkilerinin önemini anlamayı ve değerlendirmeyi amaçlayan evresidir. Etki değerlendirme aşaması, yaşam döngüsü envanter analizlerini, potansiyel çevresel etkilerin miktarını ve önemini değerlendirmektedir. Karakterizasyon faktörlerine göre girdiler ve çıktılar, önce etki kategorilerine atanır ve potansiyel etkileri nicelleştirilir. Etki aşaması girdi ve çıktılar hakkında pek çok bilgi sağlamaktadır. Etki değerlendirme evresinde seçim yöntemi, modelleme ve etki kategorilerinin ağırlıklandırılması gibi yöntemler öznellik taşıyabilmektedir. Bu nedenle varsayımların ve kabullerin açıkça tanımlanması şeffaflık açısından kritik bir önem taşımaktadır (ISO 14040, 2006)

ISO 14040 (2006)'a göre zorunlu ve zorunlu olmayan adımlardan oluşan YDED, Şekil 5'teki gibi iki farklı şekilde kategorize edilmiştir. Çevresel etki kategorilerinin, tanımlama modellerinin ve kategori göstergelerinin seçilmesi, envanter sonuçlarının seçilen çevresel etki kategorilerine göre düzenlenmesi ve sonuçların hesaplanması zorunlu adımlardır. Normalleştirme, ağırlıklandırma ve gruplandırma ise YDD sonuçlarının açıklanmasına yardımıı olabilen zorunlu olmayan adımlardır (ISO 14040, 2006). 


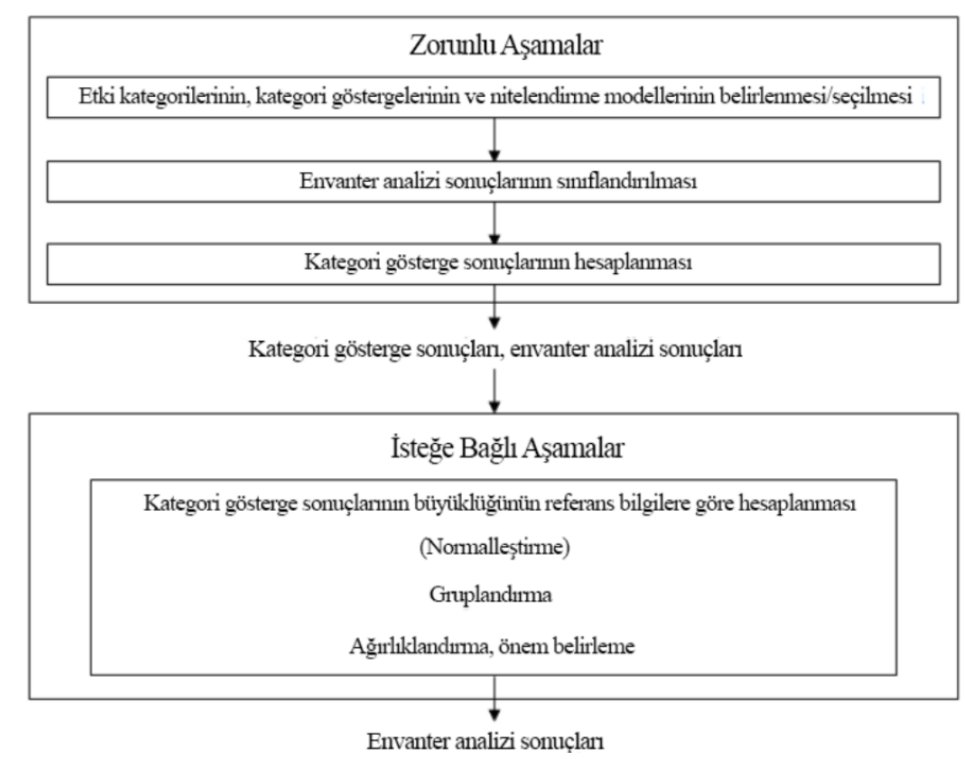

Şekil 5. Etki Değerlendirmesini Oluşturan Basamaklar (ISO 14040, 2006)

\subsubsection{Yaşam Döngüsü Yorum ve Sonuç Aşaması}

4. ve son aşamadır. YDD'nin sonuçlarına ulaşabilmek ve tavsiyelerde bulunabilmek amacıyla, envanter analizi veya etki değerlendirmesi aşamalarının birisinden veya her ikisinden elde edilen sonuçların, çalışmanın amaç ve kapsamına uygun bir şekilde değerlendirildiği aşamadır (TS EN ISO 14044, 2007).YDD'de sonuç olarak elde edilen alternatiflerin karşılaştırılması karmaşık bir süreçtir. Bunun en büyük nedeni, etki değerlendirmesi ve envanter analizi aşamaları esnasında yapılan varsayımların, kişiye veya kuruma göre değişebilen tercihe dayalı seçimler olmasıdır. Verilerden ulaşılan sonuçlar tüm kullanıcıların bütünsel ve açık olarak değerlendirebilmesi için, çalışmanın sonunda raporlanmalıdır. Bu rapor çalışmanın tümünü yansıtmalı ve karar vericilerin ve okuyucuların kullanacağı rehber kitap niteliğinde olmalıdır. Sonuçların çok net olmadığı durumlarda alternatiflerin karşılaştırılması mümkün olmamakta ve bu yapılan çalışmaların boşa gittiği şeklinde yorumlanmamalıdır. Aksine, karar verme aşamasının daha da önem kazandığının bir göstergesidir (Demirer, 2011).

\subsection{Yasam Döngüsü Değerlendirme Yönteminin Uygulama Sınırları}

YDD çalışmalarının sınırları, hangi aşamada başlayıp hangi aşamaya kadar devam ettiğine göre isimlendirilmektedir. Hammadde elde edilmesine (beşik), ürünün kullanımının son bulmasına (mezar), hammaddenin fabrikaya iletildiği aşamaya (kap1) denilmektedir. Bir ürün ya da prosesin tüm yaşam döngülerini kapsayan YDD’ye 'beşikten mezara'; hammadde çıkartılmasından fabrikaya iletilmesine kadar olana 'beşikten kapıya'; bertarafindan sonra atıkların geri kazanımı söz konusu ise 'beşikten beşiğe'; bir ürün ya da prosesin sadece üretim aşaması söz konusu ise 'kapıdan kapıya' olarak isimlendirilmektedir. YDD sistem sınırları Şekil 6' da şematize edilmiştir (PE International, 2017).

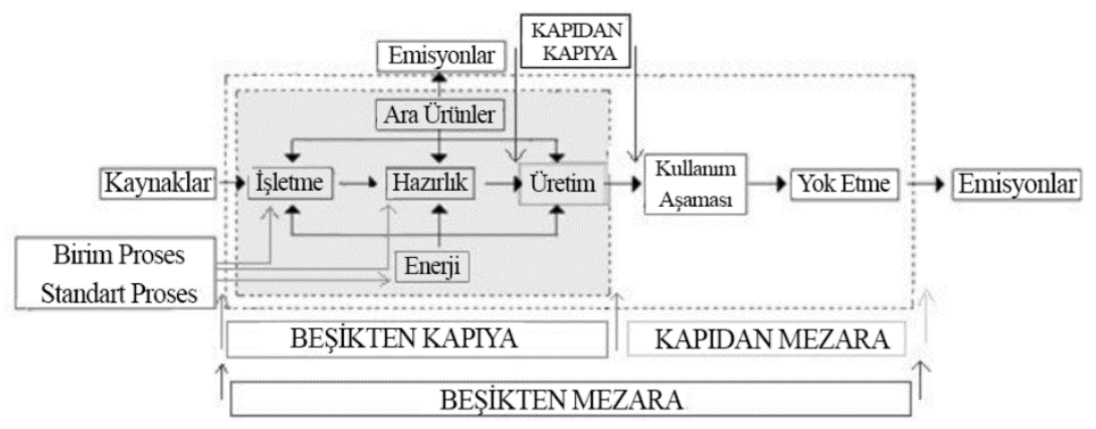

Şekil 6. YDD Sistem Sınırları (PE International, 2017)

8 | $\mathrm{P}$ a g e

www.iiste.org 
Herhangi bir ürün, süreç ya da yapım sisteminin; teknik ve fonksiyonel performansının yanı sıra, çevresel etkilerinin kapsamlı bir şekilde analiz edilmesi gereklidir. Yapı malzemesinin çevresel etkilerini değerlendiren bu sistemin uygulanması yapılacak olan herhangi bir çalışma için sınır çizmektedir. Literatürde sistem sınırları olarak da ifade edilen bu sınırlar, bir YDD çalışmasının kapsayacağı alanı belirlemek açısından önemlidir (Curran, 2006).

\section{Sonuç}

$\mathrm{Bu}$ çalışma kapsamında farklı tez, makale, kitap gibi çeşitli yayınlardan literatür taraması yapılarak, sürdürülebilirlik, yeşil bina kavramları ve Yaşam Döngüsü Değerlendirmesi başlıkları ile ilgilikapsamlı tanımlamalar yapılmıştır. Bir ürün veya hizmetin üretimi ile başlayan hammaddelerin üretim alanına nakliyesi, fabrikada ürünün imal edilmesi, inşaat alanına nakliyesi, yerine takılması, kullanımı, bakım onarımı, bertaraf edilmesi ve yeniden kullanımına kadar geçen süreçler gibi her türlü evrenin titiz şekilde planlanarak hareket edilmesinin önemi vurgulanmış ve değerlendirmelerde bulunulmuştur. Yapılan analiz ve değerlendirme sonrasıelde edilen sonuçlar aşağıda belirtilmiştir:

- Ekolojik dengenin zamanla hasar görmesi sonucunda sürdürülebilirlik, yeşil bina kavramlarının önem kazandığı görülmektedir. Çevredeki artan olumsuz değişikliklerde California Integrated Waste Management Board'da (CIWMB, 2000) belirtildiği gibi inşaat sektörünün de payı büyüktür. Nihai olarak çevreye duyarlı yaklaşımlar ile sürdürülebilir ve yeşil bina kavramları, mimarlık ve inşaat disiplininde yerini almıştır. Yenilenebilir enerji kaynaklarına yönelen doğal kaynakların uygun şekilde tüketimini oluşturan bir ürünün, sistem içindeki üretimden sistem sonundaki bertarafina kadar bütün safhalarının baştan sona incelenmesi sağlanmıştır.

- Mevcut sürdürülebilirlik kavramının tanımlaması yapılarak, daha iyi anlaşılabilmesi için tarihsel süreci gözden geçirilmiş ve kavramın yaygınlaşmasındaki olumsuz etkenlere yer verilmiştir.

- Yeşil binaların mevcut karakteristik özellikleri ve amaçları belirtilerek kavramın çerçevesi belirlenmiştir.

- Yeşil bina değerlendirme sistemlerinden olan, Yaşam Döngüsü Değerlendirmesinin ortaya çıkış süreçleri hakkında bilgi verilirken, farklı tanımlar ele alınmıştır.

- Yaşam Döngüsü Değerlendirmesi, bir ürünün faydalı ömrü boyunca çevresel etkilerinin büyüklügünü ve önemini anlamaya yarayan değerlendirme sistemidir.

- YDD'nin 15 farklı uygulama alanına örnekler verilmiştir. Uygulama alanlarında en çok ürün/proses geliştirmenin etkili olduğu anlaşılırken, hangi çalışmalara öncülük ettiği grafiklerle ortaya konmuştur.

- Yapı malzemesinin yaşam döngüsünün üç farklı kullanım süreci üzerinden ilerlediği belirtilerek, süreç boyunca malzemelerin iyileştirilmesi, geliştirilmesi ve çevresel etkilerinin değerlendirmesi için malzemenin yaşam döngüsünün önemi vurgulanmıştır.

- Kamu ve özel sektörde geniş bir perspektifte kullanıldığı bilinen YDD'nin, stratejik planlama, öncelik belirleme, ürün ve hizmetlerin tasarımı ve mevcut tasarımların yenilenmesi gibi konulardaki yetkinliğinden bahsedilerek güçlü yönleri ortaya konulmuştur. Belirtilen tüm süreçlerin ciddi emek ve zaman istemesinden ötürü çeşitli zayıf yönleri de saptanmıştır.

- Amaç kapsam tanımı, envanter analizi, etki değerlendirmesi ve yorumlama olarak 4 farklı aşamadan oluşan YDD'nin, belirtilen evreler üzerinden yol haritası incelenmiştir. Aşamaların tanımları ve evreler arası izlenilecek yollar hakkında bilgi verilmiştir.

- YDD’nin sınırlarında etkili olan temel kavramlar tanımlanmıştır. Beşik, kapı, mezar kavramlarının 4 farklı kombinasyonundan oluşan, beşikten kapıya, beşikten mezara, kapıdan kapıya, kapıdan mezara süreçleri hakkındaki bilgiler şekil üzerinden aktarılmışır.

Bu çalışma gerek mimarlık ve mühendislik sektöründe gerekse Yaşam Döngüsü Değerlendirmesinin baz alındığ çalışmalarda örnek teşkil etmesi, kaynak sağlaması amacıyla yapılmıştır. Birçok farklı sektöre doğrudan etki eden YDD'nin çerçevesinin belirlendiği bu kapsamda, ileride yapılacak benzer çalışmalara ışı tutması öngörülmektedir. 


\section{Kaynaklar}

Adler, A., Armstrong, J. E., Fuller, S. K., Kalin, M., Karolides, A., Macaluso, J., Walker, H. A., (2006). Yeşil Binalarda Proje Planlama ve Maliyet Tahmini, 2. Ed., R. S. Means, Kingston, Mass, ABD.

Bishop, P. L. (2000). Kirlilik Önleme: Temel Bilgiler ve Uygulanmas1, 1. baskı. McGraw-Hill, Montgomery, ABD.

Buyle, M., Braet, J., ve Audenaert, A., (2013). İnşaat Sektöründe Yaşam Döngüsü Değerlendirmesi: Bir İnceleme. Yenilenebilir ve Sürdürülebilir Enerjiler Üzerine İncelemeler, Antwerp, Belçika, vol. 26, ss. 379-388, Oct.

California Integrated Waste Management Board (CIWMB), (2000). Designing with vision: a technical manual for materials choices in sustainable construction, California Integrated Waste Management Board, ABD, p. 1-2.

Caradonna, J. (2014). From Concept to Movement. Sustainability, A History. Oxford University Press, Oxford, England.

Curran, M.A., (2006). Yaşam Döngüsü Değerlendirmesi: İlkeler ve Uygulamaları, EPA/600/R06/060 U.S. Çevreyi Koruma Ajans1, Ohio, ABD, s. 1-54.

Çelebi, G., Aydın, A.B. (2001). Sürdürülebilir Mimarlık yaklaşımında yapı malzemelerinin irdelenmesi, IV. Ulusal Ekoloji ve Çevre Kongresi, İzmir, Türkiye, s. 457-464.

Çokaygil, Z. (2005). Atık Yönetimi Planlamasında Yaşam Döngüsü Analizi, Yüksek Lisans Tezi, Anadolu Üniversitesi, Fen Bilimleri Enstitüsü, Çevre Mühendisliği Ana Bilim Dalı, Eskişehir, Türkiye.

Demirer, G. N. (2011). Yaşam Döngüsü Analizi, Pratik Yaşam Döngüsü Analizi Klavuzu AB Sürecinde İşletmeler ve Kamu için Yaşam Döngüsü Analizi Yöntem ve Örnekleri, 1. Bask1, Bölgesel Çevre Merkezi REC, Ankara, Türkiye.

Esin, T. (2007). Yapı Malzemeleri Üretim Sürecinin Çevresel Etki Analizi İle İlgili Bir Çalışma, Building and Enviroment, Bina ve Çevre, 42: 3860-3871, Gebze Üniversitesi, Mimarlık Fakültesi, Teknoloji Enstitüsü, Kocaeli, Türkiye.

International Organization of Standardization (ISO), (2006). Çevre Yönetimi, Yaşam Döngüsü Değerlendirmesi Prensipleri ve Çerçevesi, ISO 14040, Geneva, İsviçre, s. 1-20.

Jensen, A.A., Hoffman, L., Moller, B., Schmit, A., Christiansen, K., Elkington, J., Dijk, F.V., (1997). Life cycle assessment, a guide to approaches, experiences and information sources. European Environment Agency, Denmark, p. 13-14, 51-71.

Kaya, S. S. (2010). Bina Yaşam Döngüsünde Enerji Analizi ve Yeşil Binalar, Yüksek Lisans Tezi, Ege Üniversitesi, Fen Bilimleri Enstitüsü, İzmir, Türkiye.

Kim J.J., Rigdon, B. (1998). Mimari Modül: Sürdürülebilir Yapı Malzemelerinin nitelikleri, kullanımı ve örnekleri, Graves J, Ulusal Kirlilik Önleme Merkezi Yüksek Eğitimi, Ann Arbor, $\mathrm{ABD}, \mathrm{s} .16,17$.

Kömürlü, R., Sayın, M., (2019). Yeşil Bina Üretimi Kapsamında Yaşam Döngüsü Değerlendirme Yönteminin İncelenmesi. ERASMUS Fen, Mühendislik ve Mimarlık Bilimlerinde Uluslararası Akademik Çalışmalar Sempozyumu, İzmir, Türkiye. 
Kömürlü, R., Arditi, D. (2017). Project Management in Green Building Production. Ecology, Planning and Design. Koleva, I., Duman Yuksel, U., Benaabidate, L. (Editors), St. Kliment Ohridski University Press Sofia, ISBN: 978-954-07-4270-0, Chapter 1, P: 1-11.

Kömürlü, R., Gurgun, P., ve Somalı, B. (2013). Yeşil Bina Sertifikalandırma Süreç Yönetimi ve Kullanım Aşamasında Sağlanan Faydaları, Mimarlıkta Malzeme Dergisi, TMMOB Mimarlar Odası İstanbul Büyükkent Şubesi Süreli Yayını, İstanbul, Türkiye. Y11. 8, Sayı. 24, s. 57-63.

Özgünler, M. (2018), Yeşil Binalar ve Yangın Güvenliği (Green Building and Fire Safety), Yap1 Dergisi (Building Journal), Şubat, İstanbul, Türkiye. Sayı. 434, ISSN 1300-3437, s. 56.

Özmehmet, E. (2005), Sürdürülebilir Mimarlık Bağlamında Akdeniz İklim Tipi İçin Bir Bina Modeli Önerisi, Yüksek Lisans Tezi, Dokuz Eylül Üniversitesi, Fen Bilimleri Enstitüsü, İzmir, Türkiye.

Öztaş S., Tanacan L. (2015). Türkiye'de Yapı Malzemeleri Sektörü İçin Geliştirilen Yaşam Döngüsü Etki Değerlendirme Modelinin Doğrulanması, 2. Uluslararası Sürdürülebilir Bina Sempozyumu, Ankara, Türkiye.

PE International, (2017). GaBi Paper Clip Tutorial, Erişim linki: http://www.gabisoftware. com/fileadmin/GaBi_Manual/GaBi_Paperclip_tutorial_Part1.pdf [Erişim Tarihi: 02.10.2020].

Saka, İ. (2011). Sürdürülebilirlik açısından İstanbul'da bir ofis binasının LEED sertifikalandırma sistemi kapsamında değerlendirilmesi, Yüksek Lisans Tezi, İstanbul Teknik Üniversitesi, Fen Bilimleri Fakültesi, Mimarlık Ana Bilim Dalı, İstanbul, Türkiye.

Sayın, M. (2020), Yeşil Bina Üretiminde Yaşam Döngüsü Değerlendirme Yöntemi Kapsamında Çevresel Ürün Beyanlarının Yapılarda Uygulanması, Yüksek Lisans Tezi, Kocaeli Üniversitesi, Fen Bilimleri Enstitüsü, Mimarlık Ana Bilim Dalı, Kocaeli, Türkiye.

Simonen, K. (2014). Pocket Architect: Teknik Tasarım Serisi Yaşam Döngüsü Değerlendirmesi, 2. Ed. New York, USA.

TS EN ISO 14044, (2007). Çevre Yönetimi, Hayat Boyu Değerlendirme, Gerekler ve Kılavuz, İstanbul, Türkiye.

Williams, A. S. (2009). Life cycle analysis: a step by step approach, Rep.TR-040 Illinois Sustainable Technology Center, Illinois, USA.

Yıldız, N.B. (2017), Cam Elyaf Takviyeli Beton (GFRC) Cephe Panelleri İçin Yaşam Döngü Değerlendirmesi (YDD) Yöntemiyle Bir Sürdürülebilirlik Çerçevesi Geliştirilmesi, Doktora Tezi, Düzce Üniversitesi, Fen Bilimleri Enstitüsü, Kompozit Malzeme Teknolojileri Ana Bilim Dalı, Düzce, Türkiye. 